\title{
Ovine follicular fluid inhibits thymidine incorporation by 3 T3 fibroblasts in vitro
}

\author{
R. S. Carson, D. M. Robertson* and J. K. Findlay \\ Medical Research Centre, Prince Henry's Hospital, St Kilda Road, Melbourne, Victoria 3004, \\ Australia; and ${ }^{*}$ Department of Anatomy, Monash University, Clayton, Victoria 3168, Australia
}

\begin{abstract}
Summary. The ability of antral follicular fluid obtained from sheep follicles to inhibit 3T3 fibroblasts maintained for $48 \mathrm{~h}$ in concentrations of fetal calf serum optimal for cell growth was examined. Addition of pooled follicular fluid to cultures resulted in a dose-dependent and reversible inhibition of $\left[{ }^{3} \mathrm{H}\right]$ thymidine incorporation. Serum from ovariectomized ewes, fetal calf serum, bovine inhibin, oestradiol-17 $\beta$, testosterone, cortisol or progesterone were without effect over a range of doses. Treatment of pooled follicular fluid with charcoal-dextran did not reduce inhibitory activity which was only partly removed by heating at $85^{\circ} \mathrm{C}$. Fluid obtained from large follicles $(>5 \mathrm{~mm})$ was more potent as an inhibitor than was fluid obtained from smaller $(<5 \mathrm{~mm})$ follicles. Gel chromatography of pooled fluid resolved two peaks of inhibitory activity associated with material of $M_{\mathrm{r}} \sim 180000$ and $<10000$ respectively. No inhibitory activity was evident in fractions of serum from ovariectomized ewes chromatographed in an identical manner. These results indicate that ovine follicular fluid contains two components able to inhibit reversibly mitosis of $3 \mathrm{~T} 3$ fibroblasts in vitro.
\end{abstract}

Keywords: fibroblast mitosis in vitro; inhibition; ovarian follicular fluid

\section{Introduction}

Marked changes in functional capacity and mitotic activity of thecal and granulosa cells occur as ovarian follicles grow towards ovulation. Although the exact relationship, if any, between mitosis and differentiation of follicle cells is uncertain, increased cell mass is thought to be necessary for adequate follicular and luteal steroid secretion. In women (McNatty et al., 1979), as in sheep (Tsonis et al., 1984) and mice (Pedersen, 1970), granulosa cell proliferation takes place in the late pre-antral and early antral phases of development with very little increase in granulosa cell number in healthy follicles beyond those stages. This is said to reflect reduced mitotic activity of granulosa cells (Hirshfield \& Midgley, 1978) and suggests that mitotic activity of granulosa cells might be regulated by factors present in antral fluid.

One possible explanation of reduced mitotic activity of granulosa cells is the presence of an inhibitor of serum-derived mitogens in the antral fluid of large preovulatory follicles. We therefore examined the ability of antral fluid obtained from sheep follicles to inhibit $\left[{ }^{3} \mathrm{H}\right]$ thymidine incorporation by $3 \mathrm{~T} 3$ cells maintained in concentrations of serum optimal for cell growth.

\section{Materials and Methods}

Collection and processing of ovine follicular fluid (oFF). Ovaries were obtained from adult sheep within 10 min of slaughter and placed in ice-cold phosphate-buffered saline (PBS: $0.154 \mathrm{M}-\mathrm{NaCl}, 0.05 \mathrm{M}$-phosphate, 100 units kanamycin sulphate $/ \mathrm{ml}$ ). All subsequent processing was carried out aseptically at ice temperature. Ovaries were rinsed briefly in ethanol $(70 \% \mathrm{v} / \mathrm{v} ; 30 \mathrm{sec})$ and subsequently in fresh PBS. Follicular fluid was aspirated from all visible 
follicles over a 2-h period using a 21 -gauge hypodermic needle under gentle vacuum, pooled according to diameter of follicle ( $<5 \mathrm{~mm} ;>5 \mathrm{~mm}$ ) and centrifuged to remove granulosa cells $\left(250 \mathrm{~g}, 15 \mathrm{~min}, 4^{\circ} \mathrm{C}\right)$. Cell-free follicular fluid was stored at $-20^{\circ} \mathrm{C}$ for various periods before thawing, filter sterilization $(0 \cdot 22 \mu \mathrm{m})$ and addition to 3T 3 cell cultures.

As indicated, 1-ml samples of unfractioned oFF or chromatographic fractions of oFF were heated at $85^{\circ} \mathrm{C}$ for $15 \mathrm{~min}$, cooled to ice temperature and centrifuged $(2500 \mathrm{~g})$ to remove heat-precipitated material before addition to 3 T3 cells.

Cells and culture. Swiss mouse embryonic lung fibroblasts (3T3; Flow Laboratories, North Ryde, NSW) were maintained in tissue culture flasks (Costar, Cambridge, MA, U.S.A.) containing medium (DMEM; Dulbecco's minimal essential medium) supplemented with fetal calf serum (FCS; $2.5 \% \mathrm{v} / \mathrm{v}$ ), non-essential amino acids, glutamine $(2 \mathrm{mM}$ ) and antibiotics ( 100 units streptomycin sulphate $/ \mathrm{ml} ; 100 \mu \mathrm{g}$ penicillin $/ \mathrm{ml}$ ) and passaged at intervals which did not permit confluence to be reached. Cells were harvested by trypsinization, washed twice and resuspended at $5 \times 10^{4}$ cells $/ \mathrm{ml}$ medium containing FCS $(5 \% \mathrm{v} / \mathrm{v})$ and $\left[{ }^{3} \mathrm{H}\right]$ thymidine $(20 \mathrm{~nm}$; sp.act. $0 \cdot 4 \mathrm{Ci} / \mathrm{ml}$; Amersham International, Amersham, U.K.). Aliquants $(100 \mu \mathrm{l})$ of this suspension were transferred to individual culture wells and the total volume of each well was adjusted to $200 \mu \mathrm{l}$ by addition of test substance or medium alone $(0 \%$ FCS). After $48 \mathrm{~h}$ at $37^{\circ} \mathrm{C}$ in an humidified atmosphere of $\mathrm{CO}_{2}(5 \%)$ in air, media were removed by aspiration and cells lysed in $10 \%(\mathrm{w} / \mathrm{v})$ trichloracetic acid (TCA). Radioactivity in TCA-insoluble material was determined and expressed as a percentage of that in cultures to which no test substance had been added (control). Estimates of relative potency were based on comparison of dose-response curves obtained from at least 3 doses of test substance using regression analysis (Finney, 1964; Borth, 1976).

To examine whether the inhibitory effect of oFF on $\left[{ }^{3} \mathrm{H}\right]$ thymidine incorporation by $3 \mathrm{~T} 3$ cells was reversible, cells were grown for $48 \mathrm{~h}$ in complete culture medium (2.5\% FCS DMEM) supplemented with oFF (20\% v/v), washed, and subsequently grown for a further $48 \mathrm{~h}$ in complete medium supplemented with $\left[{ }^{3} \mathrm{H}\right]$ thymidine only. Thymidine incorporation was compared to that in cells grown for $96 \mathrm{~h}$ in the presence of oFF $(20 \% \mathrm{v} / \mathrm{v})$ or for $96 \mathrm{~h}$ in complete medium alone. In all cases, $\left[{ }^{3} \mathrm{H}\right]$ thymidine was present for the final $48 \mathrm{~h}$ of culture.

Chromatography. Pools $(50 \mathrm{ml})$ of serum from ovariectomized ewes or oFF from follicles of all sizes were chromatographed on Sephacryl S-200 $(5 \times 100 \mathrm{~cm})$ in ammonium acetate $(0.1 \mathrm{M}, \mathrm{pH} 7 \cdot 0)$ at $4^{\circ} \mathrm{C}$. Fractions of $10 \mathrm{ml}$ were collected, combined to form pools of 10 consecutive fractions and lyophilized. Absorbance of the eluant was monitored continuously at $280 \mathrm{~nm}$. Lyophilized material was reconstituted in culture medium and the pH adjusted to $7 \cdot 2$ when necessary before addition to 3 T3 cells. For studies of heat and trypsin sensitivity, fractions $20-60$ (pool I), 80-120 (pool II), and 140-170 (pool III) were combined to form three separate pools.

Heat and charcoal-dextran treatment. Pooled oFF was divided into aliquants and subjected to charcoal-dextran $\left(0.2 \%\right.$ Norit-A, $0.02 \%$ Dextran-T70, w/v) or heating at $85^{\circ} \mathrm{C}$ for 5-30 min. Pools I, II and III from S-200 chromatography of oFF were similarly heated or exposed to agarose-immobilized trypsin at $37^{\circ} \mathrm{C}$ for $1 \mathrm{~h}$. All treated material was centrifuged to remove charcoal, heat-precipitated matter or agarose-trypsin before addition to 3T3 cell cultures. Inhibitory activity in treated samples was compared to that in untreated oFF or untreated chromatographic fractions as appropriate.

Hormones. Purified inhibin $\left(M_{\mathrm{r}} 31000\right)$ was isolated from pooled bovine follicular fluid by gel chromatography, reversed-phase high-pressure liquid chromatography and preparative polyacrylamide gel electrophoresis (Robertson et al., 1986). Biological activity of this preparation was confirmed by suppression of follicle-stimulating hormone secretion by rat pituitary cells in vitro (data not shown).

Steroids were purchased commercially (Steraloids, Wilton, NH, U.S.A.) and dissolved in ethanol to give stock solutions of $2.5 \mathrm{~mm}$. Serial dilutions of stock solutions in culture medium were prepared such that the final concentrations of ethanol in cell cultures was less than $0 \cdot 002 \%(\mathrm{v} / \mathrm{v})$.

\section{Results}

Addition of FCS to cells plated in the absence of FCS resulted in a dose-dependent stimulation of $\left[{ }^{3} \mathrm{H}\right]$ thymidine incorporation (Fig. 1). Over 3 similar tests, maximal $\left[{ }^{3} \mathrm{H}\right]$ thymidine incorporation was observed at FCS concentrations of $2.5 \%(\mathrm{v} / \mathrm{v})$. For this reason, all subsequent experiments were performed in this concentration of FCS.

When oFF pooled from large ( $>5 \mathrm{~mm}$ ) follicles was added to $3 \mathrm{~T} 3$ cells maintained throughout the experiment in medium containing $2.5 \%$ FCS, a dose-dependent inhibition of $\left[{ }^{3} \mathrm{H}\right]$ thymidine incorporation was evident (Fig. 2). Further addition of equivalent amounts of serum from ovariectomized ewes or FCS to cultures initiated in $2.5 \%$ FCS were without significant effect. A survey of 5 separate pools of oFF indicated that variable levels of inhibitory activity were present in each (Fig. 3). Potency was not apparently related to the month in which oFF was collected.

When cells were grown in the presence of oFF $(20 \% \mathrm{v} / \mathrm{v})$ for $96 \mathrm{~h},\left[{ }^{3} \mathrm{H}\right]$ thymidine incorporation over the final $48 \mathrm{~h}$ was significantly lower than that by cells to which no oFF was added $(P<0.001$; 


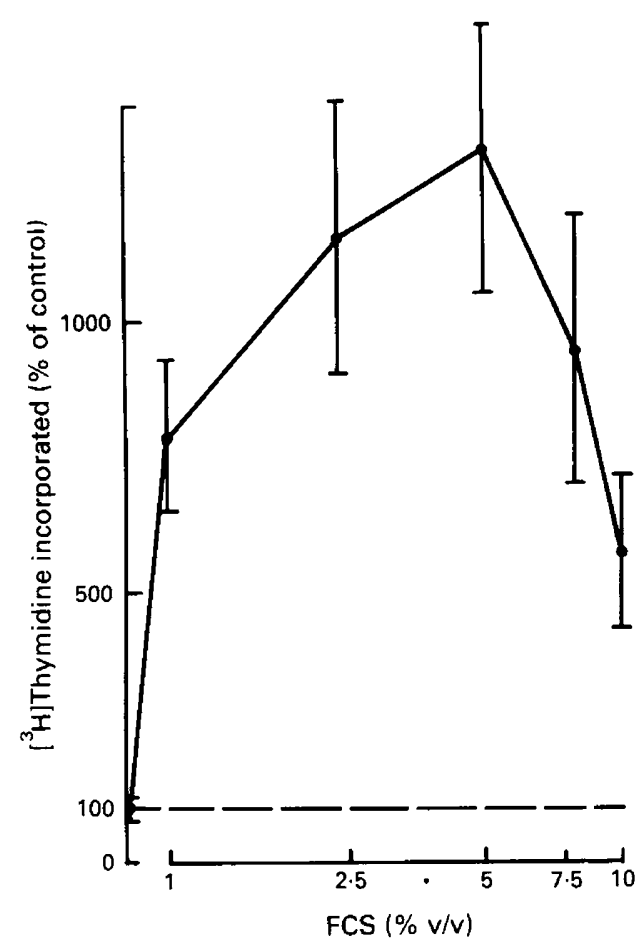

Fig. 1

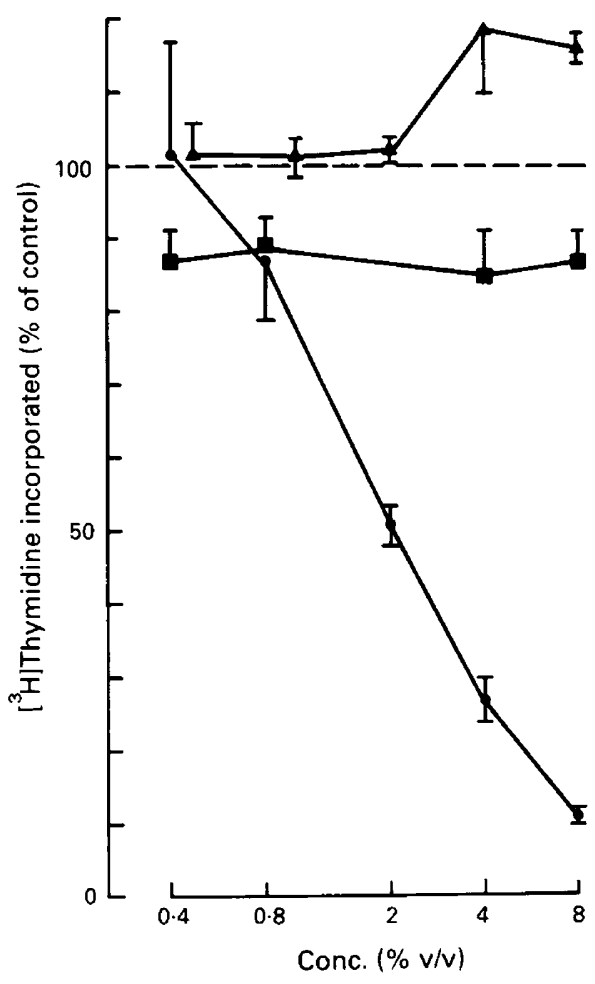

Fig. 2

Fig. 1. Determination of FCS concentrations optimal for $\left[{ }^{3} \mathrm{H}\right]$ thymidine incorporation. Cells maintained in $5 \%$ FCS were exposed to $1 \%$ FCS for $24 \mathrm{~h}$, harvested by trypsinization and plated in medium without FCS. Cells were grown for $48 \mathrm{~h}$ in the presence of $\left[{ }^{3} \mathrm{H}\right]$ thymidine and a range of doses of FCS. $\left[{ }^{3} \mathrm{H}\right]$ Thymidine incorporation is expressed as a percentage of that in cultures to which no FCS was added. Each point represents the mean of triplicate determinations ( \pm s.d.).

Fig. 2. Inhibition of $\left[{ }^{3} \mathrm{H}\right]$ thymidine incorporation by oFF. Cells were grown for $48 \mathrm{~h}$ in the presence of oFF $(\bullet)$, serum from ovariectomized ewes $(\boldsymbol{D})$ or FCS $(\boldsymbol{\Delta})$ at a range of concentrations. Values represent the mean of triplicate determinations $( \pm$ s.d. $)$.

Fig. 4). After removal of oFF from culture medium at $48 \mathrm{~h},\left[{ }^{3} \mathrm{H}\right]$ thymidine incorporation was not significantly different from control.

Incorporation of $\left[{ }^{3} \mathrm{H}\right]$ thymidine by cells exposed to a range of doses of purified bovine inhibin $\left(M_{\mathrm{r}} 31000\right)$, oestradiol-17 $\beta$, testosterone, cortisol or progesterone was not significantly different from that incorporated by cells grown in the absence of test substance (Fig. 5). In this same series of experiments, oFF inhibited, and 8-bromo cyclic AMP stimulated $\left[{ }^{3} \mathrm{H}\right]$ thymidine incorporation in a dose-dependent manner (data not shown).

Although pre-treatment of pooled oFF with charcoal-dextran did not reduce inhibitory activity relative to untreated oFF of the same pool, heating at $85^{\circ} \mathrm{C}$ resulted in partial but significant reduction of inhibitory activity. Dose-dependent suppression of $\left[{ }^{3} \mathrm{H}\right]$ thymidine incorporation by residual activity in heated oFF was parallel to that in untreated oFF. When heated for 5,15 and $30 \mathrm{~min}$, potencies relative to untreated oFF were $0.38(0.33-0.43), 0.43(0.38-0.49)$ and 0.45 $(0.39-0.51)$ respectively. The $95 \%$ confidence limits of each estimate of relative potency are stated in parentheses. 


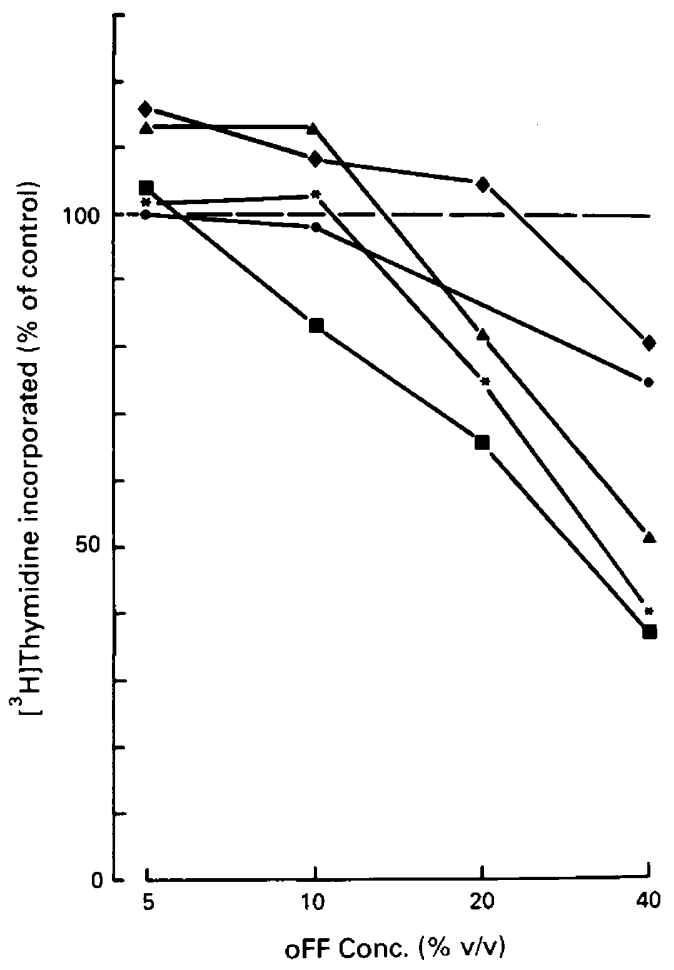

Fig. 3. Seasonal variation of inhibitory activity of oFF. Pools of oFF were collected during the months of February $(\star)$, June $(\Delta)$, July $(\boldsymbol{\bullet}, \boldsymbol{})$ and October $(\boldsymbol{\square})$ and added to cultures of $3 T 3$ cells to give final concentrations of $5-40 \%(\mathrm{v} / \mathrm{v})$. Each point represents the mean of quadruplicate determinations. Variance around each point was less than $15 \%$ and no significant differences between pools was evident at any given dose.

Control

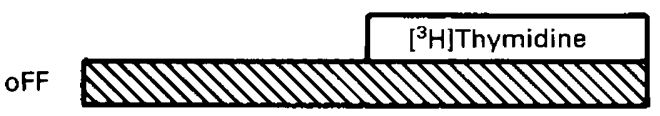

ofF:wash
[ ${ }^{3}$ H]Thymidine

$\left[{ }^{3} \mathrm{H}\right]$ Thymidine
$3822 \pm 414$ c.p.m.

$1381 \pm 218$ c.p.m.

$3776 \pm 698$ c.p.m.

Fig. 4. Reversible inhibition of mitosis by oFF. Cells were grown for $96 \mathrm{~h}$ in the absence of oFF (control), or in the presence of oFF ( $20 \% \mathrm{v} / \mathrm{v})$ for $48 \mathrm{~h}$ (oFF: wash) or $96 \mathrm{~h}$ (oFF) as indicated. $\left[{ }^{3} \mathrm{H}\right]$ Thymidine was added to all cultures at $48 \mathrm{~h}$. Results are expressed as c.p.m./culture and represent the mean of quadruplicate measurements ( \pm s.d.). 

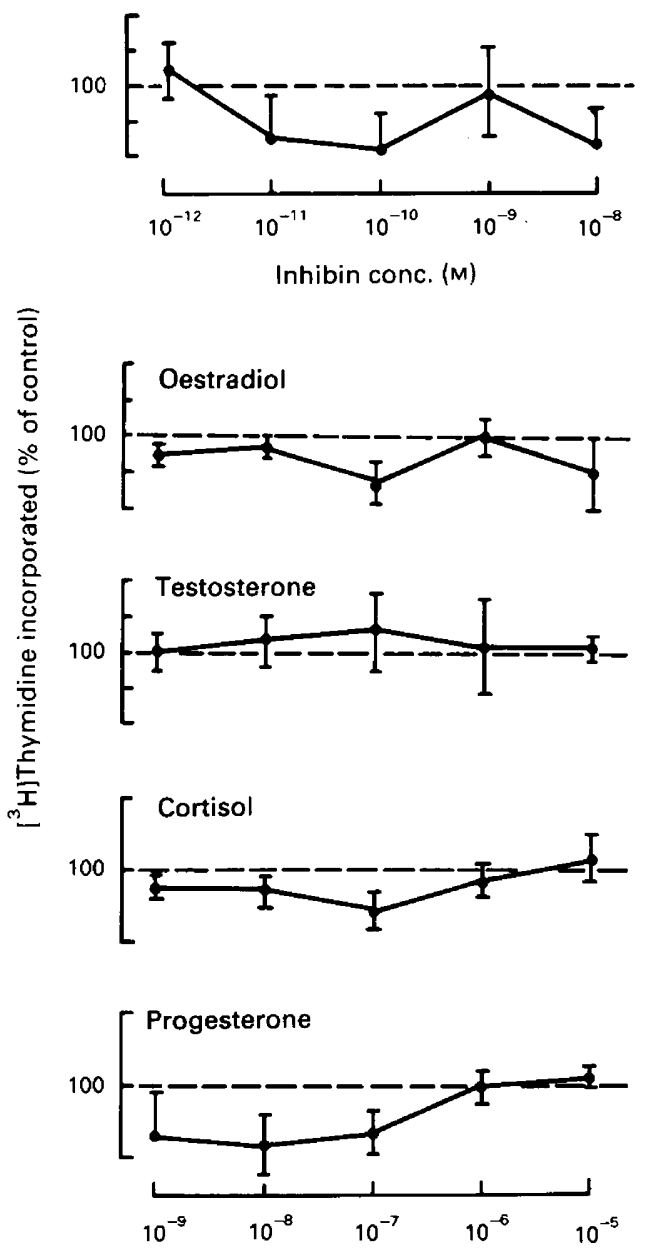

Steroid conc. (M)

Fig. 5. Effects of constituents of oFF on mitosis of 3T3 cells. Cells were grown for $48 \mathrm{~h}$ in the presence of a range of concentrations of purified bovine inhibin $\left(M_{\mathrm{r}} 31000\right)$, oestradiol-17 $\beta$, testosterone, cortisol or progesterone. Values are mean ( \pm s.d. for quadruplicate estimates) $\left[{ }^{3} \mathrm{H}\right]$ thymidine incorporation expressed as a percentage of that in cultures to which no inhibin or steroid was added (control). Divisions on each vertical axis represent an interval of $10 \%$ control.

Addition of oFF from follicles of $<5 \mathrm{~mm}$ in diameter to cultures of $3 \mathrm{~T} 3$ cells did not alter $\left[{ }^{3} \mathrm{H}\right]$ thymidine incorporation significantly when compared to that by cells cultured in the absence of oFF. Addition of oFF pooled from larger follicles ( $>5 \mathrm{~mm}$ diameter) resulted in a dose-dependent suppression of $\left[{ }^{3} \mathrm{H}\right]$ thymidine incorporation (Table 1 ).

When subjected to gel chromatography at $\mathrm{pH} 7 \cdot 0$, two peaks of inhibitory activity were eluted (Fig. 6). Of 50000 units of activity loaded $(1 \mu \mathrm{l}$ starting material $=1$ unit of inhibitory activity), 17646 units were recovered as material of $M_{\mathrm{r}} \sim 180000$ (12 194 units) and $M_{\mathrm{r}}<10000$ (5452 units). No inhibitory activity was evident in serum from ovariectomized ewes or in any eluted fractions of such serum chromatographed in an identical manner.

Neither heating at $85^{\circ} \mathrm{C}$ nor exposure to trypsin resulted in loss of inhibitory activity from the material of lower molecular weight (Fig. 7; pool III). Although the inhibitory activity associated 
Table 1. Inhibition of mitosis by oFF from small and large antral follicles

\begin{tabular}{lcccc}
\hline & \multicolumn{4}{c}{ Conc. $(\%, v / v)$} \\
\cline { 2 - 5 } Follicle & 0.5 & 1.6 & 5.0 & 16.0 \\
\hline $\begin{array}{c}\text { Small } \\
(<5 \mathrm{~mm})\end{array}$ & $101(6)$ & - & $92(16)$ & $119(18)$ \\
$\begin{array}{c}\text { Large } \\
(>5 \mathrm{~mm})\end{array}$ & $102(18)$ & $89(3)$ & $44(22)$ & $34(6)$ \\
\hline
\end{tabular}

Pools of oFF were prepared from small antral follicles $(<5 \mathrm{~mm})$ and large antral follicles $(>5 \mathrm{~mm})$ and added to 48-h cultures of $3 \mathrm{~T} 3$ cells at a range of concentrations. Results are expressed as a percentage of $\left[{ }^{3} \mathrm{H}\right]$ thymidine incorporation by cells grown in the absence of oFF (control). Values are the mean of triplicate estimates and s.d. (in parentheses).
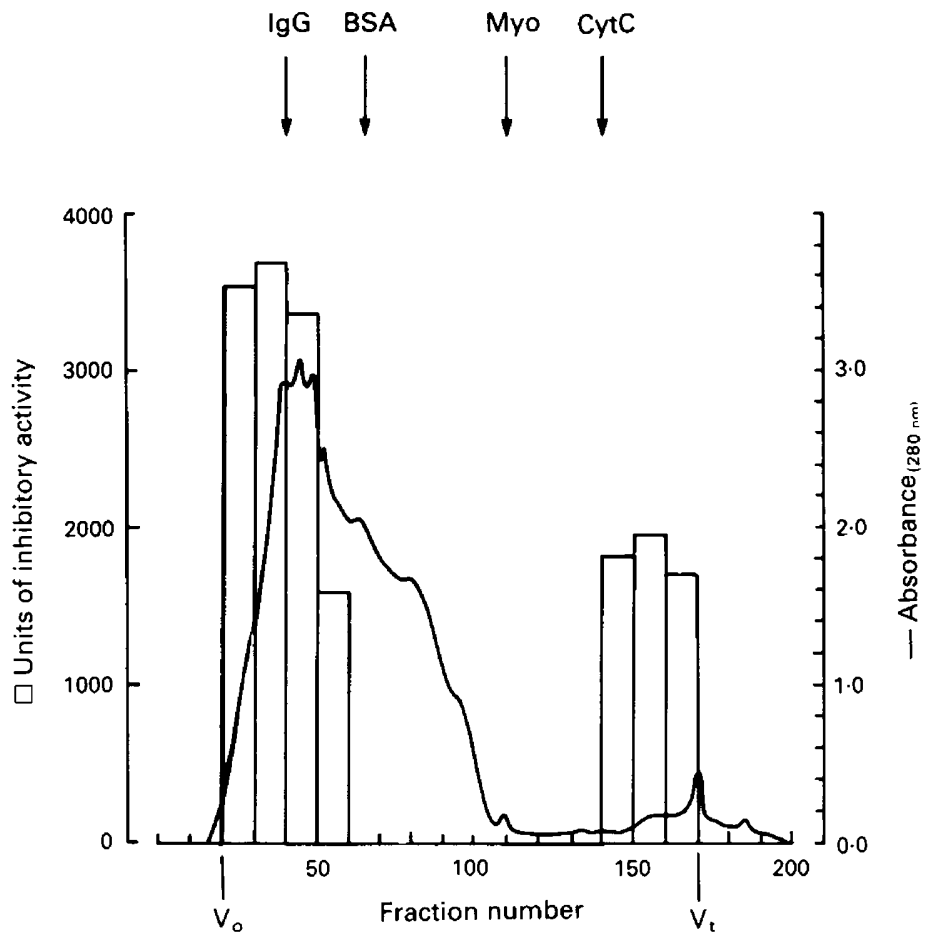

Fig. 6. S-200 chromatography of oFF. Pooled oFF $(50 \mathrm{ml})$ was chromatographed on Sephacryl

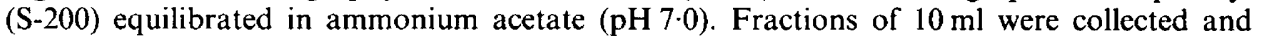
absorbance $(280 \mathrm{~nm})$ measured. Inhibitory activity was measured in consecutive pools of 10 fractions (total volume $=100 \mathrm{ml}$ ) after lyophilization and reconstitution in culture medium. Activity in reconstituted pools of eluted fractions was measured relative to that in starting material $(1 \mu \mathrm{l}$ starting material $=1$ unit of inhibitory activity). Molecular weight markers were IgG (180 000), bovine serum albumin (BSA; 67 000), myoglobin (Myo; 17200 ) and cytochrome $\mathrm{C}(\mathrm{CytC} ; 11700)$. Void volume $\left(\mathrm{V}_{\mathrm{o}}\right)$ and total column volume $\left(\mathrm{V}_{1}\right)$ are indicated. Pooled serum from ovariectomized ewes $(50 \mathrm{ml})$ was treated in an identical manner with no inhibitory activity being evident in starting material or eluted fractions (data not shown). 

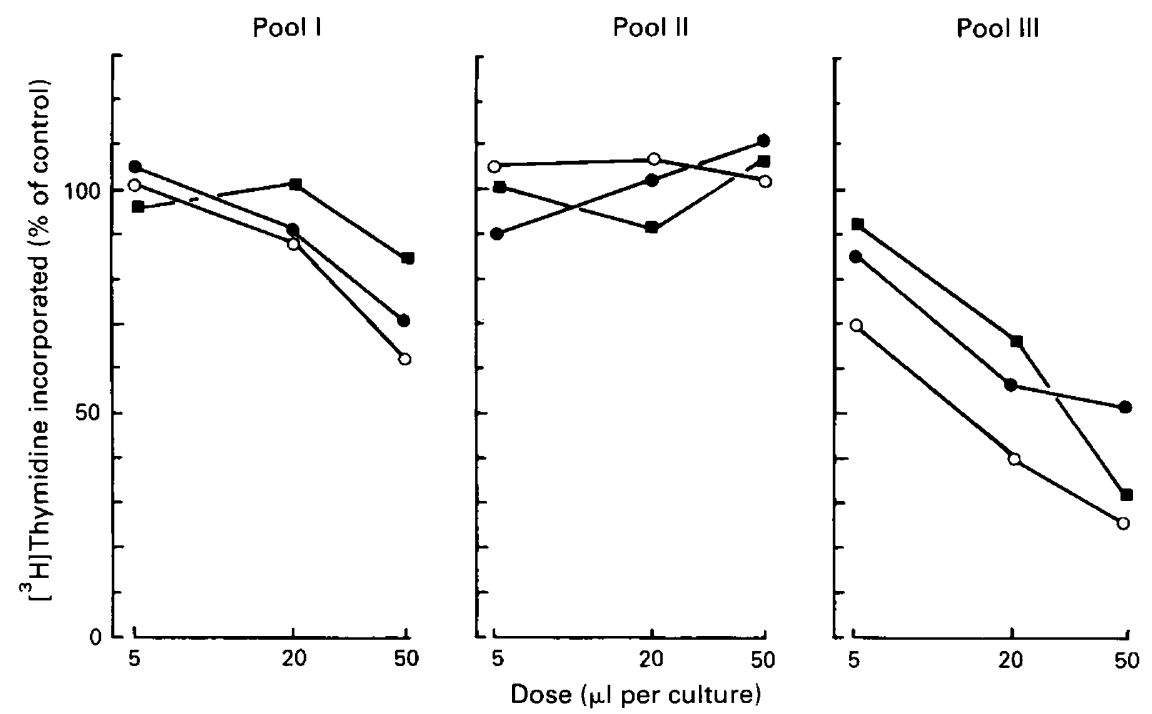

Fig. 7. Sensitivity of resolved S-200 chromatographic fractions to heating and trypsin. After S-200 chromatography of $50 \mathrm{ml}$ oFF (see Fig. 6), fractions 20-60 (pool I), 80-120 (pool II) and 140-170 (pool III) were pooled. Each pool was assayed for inhibitory activity following no further treatment $(O)$, heating at $85^{\circ} \mathrm{C}$ for $15 \mathrm{~min}(\Theta)$, or exposure to trypsin at $37^{\circ} \mathrm{C}$ for $20 \mathrm{~min}(\boldsymbol{\square})$. Each point represents the mean of quadruplicate determinations.

with material of higher molecular weight (pool I) was reduced significantly after exposure to trypsin, heating of this material was without significant effect. As control, non-inhibitory material of intermediate molecular weight (pool II) remained apparently inactive following heating or exposure to trypsin (Fig. 7).

\section{Discussion}

We have used $\left[{ }^{3} \mathrm{H}\right]$ thymidine incorporation rather than cell number or DNA content as an estimate of mitotic activity in vitro. Although this does not necessarily correlate with changes in cell number, $\left[{ }^{3} \mathrm{H}\right]$ thymidine incorporation does reflect accurately the number of cells which have progressed through the ' $S$ ' phase, a necessary requisite of cell division. Based on $\left[{ }^{3} \mathrm{H}\right]$ thymidine incorporation, our data indicate that oFF inhibits serum-induced mitosis of 3T3 fibroblasts in vitro. This effect is both dose-dependent and reversible in that washing of oFF from cultures resulted in complete restoration of serum-induced mitotic activity.

Inhibitory activity recovered from oFF was associated with material of $M_{r} \sim 180000$ and $<10000$, suggesting that either two very distinct components of oFF are each capable of inhibiting mitosis, or that the material of higher molecular weight represents active material bound to a carrier protein. Incomplete loss of activity at $85^{\circ} \mathrm{C}$ suggested that oFF contained both heat-labile and heat-stable inhibitory components. This would be consistent with the observed chromatographic heterogeneity of inhibitory activity. Given that the component of lower molecular weight was stable to both heating and exposure to trypsin, the material of higher molecular weight would be expected to be heat-sensitive to explain the partial reduction in inhibitory activity after heating unfractionated oFF. However, although the component of higher molecular weight was trypsinsensitive, heating had little or no effect. The reduction in inhibitory activity after heating of unfractionated oFF must therefore have been due to interaction with other components of follicular fluid, possibly endogenous proteases.

Failure of charcoal treatment of oFF to remove inhibitory activity and an inability of exogenous steroids to reduce mitotic activity further argue against the inhibitory components being 
steroidal in nature. In view of the concentrations of steroids (Carson et al., 1981), and of inhibin in oFF (Tsonis et al., 1983), and the manner in which the present experiments were conducted, it is estimated that the final concentrations of steroids and inhibin in culture media to which oFF had been added would have been of the order $10^{-8} \mathrm{M}$. Concentrations of inhibin and exogenous steroids studied in these experiments were several orders of magnitude above and below this level.

Purified bovine inhibin of $M_{\mathrm{r}} 31000$ prepared in this laboratory (Robertson et al., 1986) did not alter mitotic activity of 3T3 fibroblasts. It is established that the alpha subunit of inhibin has extensive homology with the constituent subunit of homodimeric transforming growth factor type beta (TGF- $\beta$; Mason et al., 1985), a factor capable of both stimulation and inhibition of mitosis in normal tissues (see Moses et al., 1985, for review). Our data suggest that, despite extensive structural homology, inhibin does not share any functional domain with TGF- $\beta$ or that each is similarly active and 3T 3 cells under these experimental conditions do not respond to TGF- $\beta$-like activity.

Tissue-specific endogenous inhibitors of mitosis are said to exist in a variety of non-neoplastic tissues including liver (Verley et al., 1971), cerebral cortex (Johnson et al., 1985), serum (Del'Aquilla et al., 1984) and testis (Thumann \& Bustos-Obregon, 1982). We are unable to state the relationship, if any, of the activity described in the present study with any of these inhibitors from other tissues or the inhibitors of embryo cleavage (Hung \& Millard, 1985), oocyte maturation (Tsafriri \& Channing, 1975), pituitary FSH secretion (Robertson et al., 1986), gonadotrophin binding (Yang et al., 1976; Darga \& Reichert, 1978), granulosa cell luteinization (Ledwitz-Rigby et al., 1977) or gonadotrophin-induced follicular development (diZerega et al., 1982, 1983) said to be present in follicular fluid. Because mitosis of granulosa cells is said to be independent of pituitary gonadotrophins (Gospodarowicz \& Bialecki, 1979) it is unlikely that, in the ovary, inhibitors of mitosis are related to inhibitors of gonadotrophin binding to ovarian cells.

It is possible that inhibition of mitosis by oFF reflects the presence in oFF of factors capable of blocking the effects of mitogens present in FCS. Possible mechanisms of action at this level include binding and inactivation of mitogens by components of oFF, inhibition of interaction of mitogens with cellular receptors, or disruption of mitogen-induced subcellular responses. There is evidence for the testis that endogenous inhibitors of mitosis block the binding of epidermal growth factor (EGF) to its receptor and thus EGF-induced mitosis of testicular cells (Holmes et al., 1986). Alternatively, inhibition of serum-induced mitosis may be due to the presence in oFF of inhibitors which interact directly with $3 \mathrm{~T} 3$ cells to block thymidine uptake or metabolism rather than blocking the effects of mitogens in FCS.

In addition to 3T3 cells (Makris et al., 1983), cells derived from the mouse embryo (Hung \& Millard, 1985), human ovarian tumour (Kikuchi et al., 1986) and bovine aortic endothelium (Koos, 1986) have been used to study regulation of mitotic activity in vitro by ovarian factors. There is also experimental evidence in support of regulation of testis cell proliferation by seminiferous tubule growth factor (Bellve \& Feig, 1984) which is based on studies of 3T3 rather than testis cells. Attempts to compare the effect of an endogenous ovarian growth factor on proliferation of 3T3 and granulosa cells have as yet proved inconclusive (Makris et al., 1983).

Even though 3T3 fibroblasts have been used extensively as a bioassay for growth factor activity and in studies of the control of mammalian cell proliferation, confirmation of an inhibitory factor in oFF is entirely contingent on demonstration of an inhibition of oFF of granulosa cell rather than 3T3 fibroblast mitosis in vitro. Despite this reservation, it remains possible that the ability of oFF to inhibit serum-induced mitosis may account for the observed inhibition of gonadotrophin-induced follicular development when charcoal-treated oFF was administered to sheep (Cahill et al., 1985).

We thank the MH\&MRC (Australia), the Australian Meat \& Livestock Research and Development Corporation for financial assistance; Angela Vitali, Lorraine Leversha, Jennifer Smith and Marianne De Garis for technical assistance; and Jenny Judd and Joan Williams for typing the manuscript. 


\section{References}

Bellve, A.R. \& Feig, L.A. (1984) Cell proliferation in the mammalian testis: Biology of the seminiferous growth factor. Recent Progr. Horm. Res. 40, 531-566.

Borth, R. (1976) Statistics of parallel line assay. In Methods of Hormone Analysis, p. 500. Eds H. Breur, D. Hamel \& H. L. Kruskemper. Thieme Verlag, Stuttgart.

Cahill, L.P., Driancourt, M-A., Chamley, W.A. \& Findlay, J.K. (1985) Role of intrafollicular regulators and FSH in growth and development of large antral follicles in sheep. J. Reprod. Fert. 75, 599-607.

Carson, R.S., Findlay, J.K., Clarke, I.J. \& Burger, H.G. (1981) Estradiol, testosterone and androstenedione in ovine follicular fluid during growth and atresia of ovarian follicles. Biol. Reprod. 24, 105-113.

Darga, N.C. \& Reichert, L.E., Jr. (1978) Some properties of the interaction of follicle-stimulating hormone with bovine granulosa cells and its inhibition by follicular fluid. Biol. Reprod. 19, 235-241.

Del'Aquilla, M.L., Pigott, D.A., Bonaquist, D.L. \& Gaffney, E.V. (1984) A factor from plasma-derived human serum that inhibits the growth of the mammary cell line MCF-7: characterization and purification. J. natn. Cancer Inst. 72, 291-298.

diZerega, G.S., Goebelsmann, U. \& Kanamura, R.M. (1982) Identification of proteins secreted by the preovulatory ovary which suppress the follicle response to gonadotrophins. J. clin. Endocr. Metab. 54, 1091-1096.

diZerega, G.S., Marrs, R.P., Roch, P.C., Campeau, J.D. \& Kling, O.R. (1983) Identification of a factor in pooled human follicular fluid which suppresses responses to gonadotropins. J. clin. Endocr. Metab. $56,35-41$.

Finney, D.J. (1964) Statistical Methods in Biological Assay, 2nd edn. Charles Griffin, London.

Gospodarowicz, D. \& Bialecki, H. (1979) Fibroblast and epidermal growth factors are mitogenic agents for cultured granulosa cells of rodent, porcine and human origin. Endocrinology 104, 757-764.

Hirshfield, A.N. \& Midgley, A.R., Jr. (1978) Morphometric analysis of follicular development in the rat. Biol. Reprod. 19, 597-605.

Holmes, S.D., Spotts, G. \& Smith, R.G. (1986) Rat sertoli cells secrete a factor which blocks epidermal growth factor (EGF) binding to its receptor. J. biol. Chem. 261, 4076-4080.

Hung, T.T. \& Millard, M.M. (1985) Inhibition of mouse embryo cleavage by a factor present in the human preovulatory follicular fuid. J. clin. Endocr. Metab. 61, 889-904.

Johnson, T.C., Kinders, R.J. \& Sharifi, B.G. (1985) Purification of a cell growth inhibitor from bovine cerebral cortex cells. Life Sci. 37, 1117-1123.

Kikuchi, Y., Miyauchi, M., Oornori, K., Kita, T., Kizawa, I. \& Kato, K. (1986) Inhibition of human ovarian cancer cell growth in vitro and in nude mice by prostaglandin D2. Cancer Res. 46, 3364-3366.

Koos, R.D. (1986) Stimulation of endothelial cell proliferation by rat granulosa cell-conditioned medium. Endocrinology 119, 481-489.
Ledwitz-Rigby, F., Rigby, B.W., Gay, V.L., Stetson, M., Young, J. \& Channing, C.P. (1977) Inhibitory action of porcine follicular fluid on granulosa cell luteinisation in vitro: assay and influence on follicular maturation. J. Endocr. 74, 175-184.

Makris, A., Klagsbrun, M.A., Yasumizu, T. \& Ryan, K.J. (1983) An endogenous ovarian growth factor which stimulates 3T3 and granulosa cell proliferation. Biol. Reprod. 29, 1135-1141.

Mason, A.J., Hayflick, J.S., Ling, N., Esch, F., Ueno, N., Ying, S-Y., Guillemin, R., Niall, H. \& Seeburg, P.H. (1985) Complementary DNA sequences of ovarian follicular fluid inhibin show precursor structure and homology with transforming growth factor beta. Nature, Lond. 318, 659-663.

MeNatty, K.P., Moore-Smith, D., Makris, A., Osathanondh, R. \& Ryan, K.J. (1979) The microenvironment of the human follicle: interrelationships among the steroid levels in antral fluid, the population of granulosa cells and the status of the oocyte in vivo and in vitro. J. clin. Endocr. Metab. 49, 851-860.

Moses, H.L., Tucker, R.F., Loef, E.B., Coffey, R.J., Halper, J. \& Shipley, G.D. (1985) Type beta transforming growth factor is a growth stimulator and growth inhibitor. In Cancer Cells, Vol. 3: Growth Factors and Transformation, pp. 65-71. Eds J. Feramisco, B. Ozanne \& C. Stiles. Cold Spring Harbor Laboratory Press, Cold Spring Harbor.

Pedersen, T. (1970) Follicle kinetics in the ovary of the cyclic mouse. Acta endocr., Copenh. 64, 304-323.

Robertson, D.M., de Vos, F.L., Foulds, L.M., McLachlan, R.S., Burger, H.G., Morgan, F.J., Hearn, M.T.W. \& de Kretser, D.M. (1986) Isolation of a $31 \mathrm{kD}$ form of inhibin from bovine follicular fluid. Molec. cell. Endocrinol. 44, 271-277.

Thumann, A. \& Bustos-Obregon, E. (1982) In vitro assay of rat spermatogonial chalone in prepubertal seminiferous tubules. Andrologia 14, 35-42.

Tsafriri, A. \& Channing, C.P. (1975) An inhibitory influence of granulosa cells and follicular fluid upon porcine oocyte meiosis in vitro. Endocrinology 95, 922-927.

Tsonis, C.G., Quigg, H., Lee, V.W.K., Leversha, L., Trounson, A.O. \& Findlay, J.K. (1983) Inhibin in individual ovine follicles in relation to diameter and atresia. J. Reprod. Fert. 67, 83-90.

Tsonis, C.G., Carson, R.S. \& Findlay, J.K. (1984) Relationships between aromatase activity, follicular fluid oestradiol-17 $\beta$ and testosterone concentrations, and diameter and atresia of individual ovine follicles. J. Reprod. Fert. 72, 153-163.

Verley, W.C., Deschamps, Y., Puschpathadam, J. \& Desrosiers, M. (1971) The hepatic chalone I: assay method for the hormone and purification of the rabbit liver chalone. Canad. J. Biochem. 46, 1376-1383.

Yang, K.-P., Samaan, N.A. \& Ward, D.N. (1976) Characterisation of an inhibitor for luteinising hormone site binding. Endocrinology 98, 233-241. 